\title{
MARRIAGE AND PARTNERSHIP IN SERBIAN FAMILY LAW: LEGAL CONSEQUENCES
}

\section{Gordana KOVAČEK STANIĆ ${ }^{1}$}

In this paper the author analyses the family law consequences of family law unions in Serbia. Two types of family law unions are regulated: marriage and heterosexual nonmarital cohabitation. Same-sex union is not regulated at present, but the draft law is under preparation. The author analyses consequences of: personal relations, property relations, nuptial contract, family home, maintenance and exercise of parental rights.

\begin{tabular}{l|l} 
marriage \\
non-marital cohabitation \\
same-sex union \\
sansequences \\
family law
\end{tabular}

\section{Introduction}

In Serbia two types of family law unions are regulated: marriage and heterosexual non-marital cohabitation. Same-sex union is still not regulated, but currently the draft law on same-sex union is under preparation.

The Constitution of the Republic of Serbia ${ }^{2}$ in section two on human and minorities rights stipulates that 'everyone shall have the right to decide freely on entering or dissolving a marriage. Marriage shall be entered into based on the free consent of man and woman before the state body' (Art. 62/1,2). Furthermore, 'non-marital cohabitation shall be equal with marriage, in accordance with the law`(Art. 62/5).

The Family Act is the main act that regulates family law relationships. This Act makes provisions with respect to: marriage and marriage relations, relations in non-marital cohabitation, parent-child relations, adoption, foster care, guardianship, maintenance, property relations in the family, protection from domestic violence, proceedings regarding family relations and personal name. (Art. 1). ${ }^{3}$

1 | Professor, Department of Civil Law, Faculty of Law, University of Novi Sad, Serbia, g.kovacekstanic@pf.uns.ac.rs.

2 | Constitution of the Republic of Serbia, Official Gazette of Serbia no. 98/06.

3 | Family Act, Official Gazette of Serbia No.18/05 with amendments, hereinafter FA.

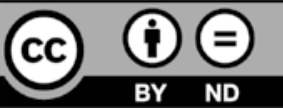




\section{Marriage/non-marital cohabitation: family law consequences}

The Serbian Family Act (FA) defines marriage as cohabitation between a man and a woman governed by the law under Article 3/1. According to this definition, the basic element of marriage is: monogamous cohabitation between two persons of the opposite sex which is governed by the law. Cohabitation is a complex relationship that involves different connections between spouses based on love, including intimate relationships, respect, maintenance and economic relationships.

The substantial requirements for a valid marriage are the following: opposite sex, expression of will to get married and lack of marriage impediments. The impediments to a marriage are: an already existing marriage, incapability of reasoning, minority, non-existence of free will, kinship by blood or adoption, affinity and guardianship (Art.15-24).

Non-marital cohabitation is a de facto relationship, which means there is no obligation, or possibility to register it. However, heterosexual non-marital cohabitation only has consequences if the legal requirements for the establishment of non-marital cohabitation are met. These requirements include the non-existence of marriage impediments and continuance on-marital cohabitation.

The main difference in legal consequences between marriage and non-marital cohabitation is in the inheritance law. According to Law on Inheritance 1995 there are no inheritance rights between partners directly from law. ${ }^{4}$ However, it is possible to make a testament and nominate a partner as a heir. Legal nature of family law consequences for spouses/partners is different. Some effects are personal, while others consider property relations or the exercise parental rights. ${ }^{5}$

\section{| 2.1. Personal consequences}

Spouses are under the obligation to cohabitate, mutually respect and help each other, and determine the place of their residence and manage the joint household consensually, but they are free to make independent decisions on their profession and work (Art. 25-27 FA). In addition Art. 348 FA governs surname options following a marriage, wherein spouses may agree to retain their surname, take their spouse's surname or add their spouse's surname or vice versa.

The Family Act does not explicitly stipulate personal relations between partners in non-marital cohabitation. Thus, the possibility of changing surnames does not exist as a consequence of non-marital cohabitation. In addition, there is a difference in affinity relations. Affinity relations are a consequence of marriage and refer to the bonds between one spouse and relatives of the other, but affinity relations do not exist in non-marital cohabitation.

4 | Law on Inheritance, Official Gazette of Serbia No. 46/95.

5 | It is also worth mentioning that the new amendment to the Law on Pension and Disability Insurance (Official Gazette of the Republic of Serbia, No. 34/03 .... 86/19) recognises the right of the nonmarital partner of the deceased person, to survivor's pension, if the cohabitation with the deceased partner lasted at least three years or the partners have a child together (Art. 28). 


\section{| 2.2. Property relations}

In Serbian law, the statutory property regime in marriage/non-marital cohabitation is the community property regime. Community property is the property that spouses/ partners acquire through work when live together (Art. 171). The property that a spouse/ partner acquires before marriage remains separate property. Property that a spouse/ partner acquires during marriage by inheritance, gift, other legal acts whereby rights are acquired exclusively, or by the division of community property becomes their separate property (Art. 168).

The Serbian Family Act has introduced the main criterion for the equal division of community property. The investigation of court practice on the division of the community property after the divorce reveals that one of the courts, namely the Court of Novi Sad, divided community property into equal parts in $75 \%$ of the cases. ${ }^{6}$

Retirement payment (severance pay) is considered to be community property. This is explicitly stated in the jurisprudence. ${ }^{7}$ This is because retirement payment is the payment derived from the work of one of the spouses during their marriage.

The stance of jurisprudence has evolved with respect to the question of disposing of immovable property in community ownership by spouses. The matter concerns cases in which one spouse disposes of such property without the consent of the other spouse. To dispose of immovable property that spouses own in community ownership, Art. 174 FA is relevant:

(1) Spouses manage and dispose of their community property jointly and consensually.

(2) It is to be considered that one spouse always undertakes operations of regular management with the consent of the other spouse.

(3) A spouse may not dispose of his/her share in community property nor may he/she burden it with legal operations inter vivos.

This means that the community property regime prevents a community property owner from disposing of their share (be it by transfer or encumbrance), taking into account that shares, although specifiable, are not specified. The community property regime comes to an end the moment they are specified in any way (ideally or physically). Given the unspecified nature of shares, the administration and disposal of things that are in the community ownership of spouses, should be exercised jointly and agreeably. ${ }^{8}$

What will happen when disposal is done in contrvention of the aforementioned rule? The answer should be simple: such disposial would be null as it runs contrary to the imperative provision. A third person cannot acquire ownership rights or any limited property right over any assets in community ownership that have been disposed of one spouse without the authorisation of other, on the basis of a legal transaction, although they can do so in accordance with general rules on good faith acquisition, or by way of adverse possession. ${ }^{9}$

6 | The investigation was rather small, from 43 cases in 32 the division of the community property was in equal parts. Thus, it is just an illustrated fact.

7 | The decision of the District Court in Valjevo, Court of Appeal, Gž 179/2007 from 5 Oct 2007.

8| More in Cvetić 2016, 2019.

9 | See: Draškić, 2020, pp. 387-388. Rules on good faith acquisition and adverse possession are devised as to protect good faith participants of legal transactions. They present secondary or alternative ways to acquire ownership, which the legislature exceptionally allows when conditions for regular acquisition are not met, so as to protect, as a rule, a good faith acquirer. 


\section{\begin{tabular}{l|l}
74 & LAW, IDENTITY AND VALUES \\
$1 \mid 2021$
\end{tabular}}

Given that rules on good faith acquisition apply only to movable things, ${ }^{10}$ when it comes to immovable things, good faith acquirers could rely only on adverse possession provided that conditions prescribed by law are met. ${ }^{11} \mathrm{~A}$ rule that protects a spouse who is not inscribed in a public registry as a holder of community ownership, can be found in Art. 176, para. 2 of FA:

It is to be considered that the entry has been made for both spouses even when only one spouse is entered, unless a written agreement on division of community property or a nuptial contract was concluded after the entry, or a court decided on the rights of the spouses regarding immovable property..$^{12}$

Acording to this rule, the law introduces an irrefutable legal presumption that immovable property, although inscribed on behalf of one spouse, belongs to both spouses as community property holders, by way of which, when it comes to proving their status, the position of a spouse who is not inscribed in the public registry has been drastically changed (rather than requring the spouse who is not inscribed to prove their status as a community property holder, athe law requires the spouse in whose name the immovable property has been inscribed needs to prove that he/she is the exclusive owner).Thus, if an immovable property was inscribed on behalf of one spouse, the other spouse could prove that the immovable property was acquired through work during marriage, and, as such, belongs to both of them in the form of community ownership of unspecifiable shares. ${ }^{13}$ To determine whether the case concerns community ownership what matters is whether the asset in qestion was acquired through work during cohabitation in marriage, ${ }^{14}$ and not whether such property has been inscribed as community ownership in the public registry.

If ownership has not been inscribed not as community ownership but as exclusive ownership by one spouse (as per rule, the husband), the aforementioned rule enables the protection of the other spouse who contributed to the acquisition of such immovable property, and who, in most cases for traditional reasons, has not been inscribed as a holder of community ownership. Indeed, the rule attempts to protect women who traditionally hold a subordinated positions in a marriage. It is a fact that women are rarely inscribed as owners of family property. The severity of the problem has been detected and, with the help of the World Bank, preparation works have been undertaken to change the regulations so as to facilitate and make it considerably affordable to inscribe both spouses as community ownership holders or co-owners. At the same time this should contribute to gender equality and an increase in the numberof women who are inscribed in the real estate cadastre, which in turn will lead to the empowerment of women and reinforce the marriage.$^{15}$ The mere fact that only one spouse is inscribed as an owner, does not affect the application of the community ownership regime, if the immovable property was acquired through work during cohabitation in marriage. ${ }^{16}$

10 | Article 31 of the Law on Foundations of Property Law Relations, Official Journal of Yugoslavia, No. 6/1980, 36/1990, 29/1996.

11 | Law on Foundations of Property Law Relations, Art. 28, 30.

12 | The rule was introduced by way of the previous Law on Marriage and Family Relations, Official Gazette of Serbia No. 22/80, 11/88.

13 | Obren Stanković in Obren Stankovic, Miodrag Orlic, Stvarno pravo, Beograd, 1996, 164, fn. 483.

14 | Family Act, Art. 171, para. 1; Draškić, 2020, pp. 397-400; Kovaček Stanić, 2007, pp. 114-115.

15 | Source of information http://www.rgz.gov.rs/default.asp, $4^{\text {th }}$ January 2017.

16 | More in: Cvetić, 2016 and 2019. 
Nevertheless, in the absence of an explicit rule for a situation where an inscribed owner disposes of such property without the authorisation of their partner, the basis of protection of the good faith of the third person, generally lies in the principle of reliance on the public registry of the rights over immovable property ${ }^{17}$ Two decisions of the Supreme Court of Cassation, ${ }^{18}$ concerning on the motions for review, which the court exceptionally allowed in order to achieve uniformity of jurisprudence ${ }^{19}$ presents a turning point from the long-enduring adverse stance of jurisprudence towards good faith acquisition through reliance on the public registry. From the facts it can be seen that the cases concerned immovable property that had been acquired through work during cohabitation in marriage, whereas only one spouse had been inscribed as the exclusive owner. The inscribed owner encumbered immovable property in community ownership regime by way of an enforceable extra-judicial hypothec based on a pledge statement (unilateral hypothec). Viewed from the relevant provisions of the Law on Hypothec,$^{20}$ the hypothec was duly established.

Taking into account the already examined rules contained in Art. 176 of Family Act, if one questions of the validity of such a disposal, the answer would be that this disposal is void, because it had been done without the consent of the other community property holder, i.e. the unregistered spouse. The fact that the community property is not registered does not prevent the unregistered spouse from filing an action seeking the nullification of a legal transaction in which the registered spouse disposed of the immovable property in community ownership without former`s consent. This would enable the entry of an annotation of a dispute prior to hypothec registration, thereby preventing the possibility of acquisition by a third party in good faith. In one case decided by the Supreme Court of Cassation, a pledge statement was given by an inscribed owner of immovable property in 2008, and an action seeking nullification in 2013. Regardless of the fact that claiming nullification of a legal transaction is not limited in terms of time, ${ }^{21}$ the good faith of an unregistered spouse is seriously disputable. The initial dishonest intention or subsequently disturbed marital relations should not affect the legal status of bona fide acquirers. If this aspect is ignored, the doors would be widely open for the deception of a hypothec creditor and good faith acquirers in general. We share the court's view that the question of an acquirer's good faith is crucial in disputes arising out of an unauthorised disposition by a community ownership holder who is inscribed as the exclusive owner. At the same time, for a fair solution, it seems essential to examine the legal position, intentions and good faith of all participants in case, so as to rule out even the least possibility circumvention of the law. Although, the aforementioned discussion shows that it is possible to protect a good faith acquirer by referring to the principle of reliance on the real estate cadastre, we deem that it would be extremely useful for the law to explicitly provide

17 | Art. 63 of the Law on State Surveying and Cadastre, Official Gazette of Serbia, No. 72/2009, 18/2010, 65/2013,15/2015 - decision of the Constitutional Court, 96/2015.

18 | Rev. 321/2014 of $5^{\text {th }}$ June 2014, available in the database Paragraf and Rev. 1981/2015 from $14^{\text {th }}$ April 2016, available at the web page of the Supreme Court of Cassastion.

19 | Art. 404 para. 1 of the Civil Procedure Law, Official Gazette of Serbia No. 72/2011, 49/2013 - decision of Constitutional Court 55/2014.

20 | Law on Hypothec, Official Gazette of Serbia No. 115/2005, 60/2015, 63/2015 - decision of Constitutional Court, 83/2015, Art. 2, Art. 8, para. 1, point 2, Art. 10, Art 15.

21 | Art. 110 of the Law on Contract and Torts, Official Journal of Yugoslavia, No. 29/1978, 39/1985, 45/1989 - decision of Constitutional Court of Yugoslavia, 57/1989, Official Journal of Yugoslavia, No. 31/1993, Official Journal of Serbia and Montenegro No. 1/2003 - Constitutional Charter. 
such a protection in cases where the right to community ownership is not inscribed in the public registry. This view is taken especially bearing in mind that in the court's reliance on the Serbia registry of rights over immovable property in acquisition related cases is outdated. The fact that women are rarely inscribed as owners and that in most cases they appear to be losers in property disposal by the husband who is inscribed as the exclusive owner, creates the impression that court' ruling that rely on the registry are unjust. Hence, a great responsibility rests on the courts when establishing facts of each concrete case. It seems that en explicit rule of the protection of a good faith acquirer would enhance legal discipline, i.e., it would force property rights' holders to consider if they intend to merit the protection provided by legal order. Ultimately, for someone who aspire to be viewed as a good faith acquirer, establishing the fact that an inscribed owner is married and if an immovable property is under exclusive or community ownership could be accepted as a surmountable obstacle in legal transactions. Nevertheless, a considerable limitation of legal transactions could be expected with regard to the corresponding application of provisions on property relations of spouses to the property relations of partners in non-marital cohabitation. The Supreme Court of Cassation is of the view that under rules contained in Art. 176, para. 2 of the Family Act, it is necessary to enter into a real estate cadastre annotation of community ownership with respect to the inscribed immovable property, so as to make it clear to the interested parties that the concerned property is under a community ownership regime. The entry of such annotations has, so far, not been envisaged by law, so we deem that an annotation would be possible only if a spouse who is not inscribed in the real estate cadastre files an action in order to establish that an immovable property is under the community ownership regime, or in order to establish nullity or voidability of a legal transaction which is used as a legal basis for unauthorised disposal of an immovable property in a community ownership regime. Inadequate regulation of examined relations and their inconsistent treatment by the courts, as an imminent consequence, could impair legal certainty in legal transactions. The rights of good faith participants in legal transactions could be brought into question by various types of spousal abuses. The practice testifies cases of law circumvention, in which spouses often resort to the fictitious divorces. However, it should be highlighted that the position of a good faith owner who is not inscribed in the real estate cadastre as a rights holder, which results from the applicable regulation on property relations of spouses, could be impaired by a sudden shift of jurisprudence with the tendency to provide protection to each person who relied on the real estate cadastre, regardless of their good or bad faith. Only a good faith acquirer can and shall deserve protection that applies also to the right holder who exercises his/her right in accordance with the principle of good faith and fair dealing, i.e., the exercise of the right could not be qualified as an abuse of law. Refusal by public notaries to authenticate a contract which envisages disposing of ownership rights over immovable property, entirely or in part, without the authorisation of the other spouse, presents a significant step forward in preventing the emergence of a document that could become susceptible for entry into the public registry, although it was made contrary to the imperative provisions. Nevertheless, where non-marital partners are concerned, it is disputable if that is an adequate way for their protection, bearing in mind that non-marital cohabitation is factual relationship in Serbian law, so a notary public cannot formally acquire knowledge of its existence (except from the partners' statements), in contrast to 
marriage whose existence can easily be established based on the excerpt from the marriage register. ${ }^{22}$

The Law on Registration Procedure with the Cadastre of Real Estate and Line Cadastre from 2018 improved this situation by introducing the obligation of the notary public and cadastre authorities to check if the buyer is married at the time of purchase of the immovable property. If they are married, they obliged to register the property as a community property in the cadastre. The property would not be registered as community property in these following situations: if both spouses make a statement that the property is separate property owned by one of them, or if they have agreed to register property as property with two owners with specific shares. ${ }^{23}$

In jurisprudence, the issue of acquiring community property during non-marital cohabitation arises. The Supreme Court of Serbia expressly stated that the property of one partner acquired during non-marital cohabitation does not become community property, if at the time of acquision, both partners were married to other persons. ${ }^{24}$ An existing marriage is an impediment to non-marital cohabitation, which has a legal effect, and prevents the creation of community property in this way. Consequently, the property becomes the separate property of the partner who purchased it. This property cannot become the community property of the spouses in an existing marriage. In order for purchased property to become community property, some legal requirements must be met. One requirement is for the spouses or partners to have been living together at the time of purchase of the property. In this case this requirement did not exist, as the partners lived in non-marital cohabitation and not with spouses. Thus, the property cannot become community property, between partners in a non-marital cohabitation, or between spouses.

\subsection{Nuptial contract and family home}

The concept of (pre) nuptial contract was introduced in Serbian law by the Family Act 2005. The authority for issuing the (pre) nuptial contract now belongs to the notary public (the authority was initially the court, according to Family Act 2005). ${ }^{25}$ The form of (pre) nuptial contract is notarial solemnisation of the legal document (Art. 188) (amendments to the Family Act 2015).

Marital contractual property regimes are specific because personal relationships exists between contracting parties. They are bound through marriage or non-marital cohabitation. This is important for the content and form of the contract. In addition, a marital contract is specific considering the fact that it is concluded with the idea of its longevity. These are the reasons why family law should provide special protection for weaker partners in relation to protection under general rules of contract law. The mechanisms for the protection of weaker partners can be either direct or indirect. Direct mechanisms takes into account the property position of the spouse/partner, and indirect mechanisms imply imperative norms about the content of the (pre) nuptial agreement and strict form of agreement. The law may prohibit contracting or exclusion of certain rules, and the possibility of contracting only regimes that are provided by the law.

22 | See more: Cvetić, 2016 and 2019.

23 | Law on Registration Procedure with the Cadastre of Real Estate and Line Cadastre Official Gazette of Serbia, No. 95/2018, Art. 7/5.

24 | Rev. 2265/2005 from 28 92006, Court practice bulletin of the Supreme Court of Serbia 1/2009.

25 | Law on Notary Public Art 82/1/10,11, Official Gazette of Serbia No. 31/2011. 
According to Serbian law, waiving the right to maintenance has no legal bearing (Art. 8 FA). The aim of this provision is to protect the weaker spouse, as the right/obligation of maintenance exists regardless of the contract. In addition, strict form of (pre) nuptial agreement is mandatory. During the act of solemnization, the notary public is obliged to warn the parties about the fact that by the nuptial agreement the legal (statutory) regime of common property would be excluded. A notary public has to include a note about doing so into the clause of solemnisation. Once issued, there is no explicit authority under the Family Act for a judge, or any other authority, to evaluate the suitability of the agreement. However, it is possible to contest the agreement in court, as any other contract.

A (pre) nuptial agreement relating to immovable property shall be registered in the public register of real estate rights, so that third parties will be in a position to become familiar with the agreement. ${ }^{26}$

Another family law consequence of marriage/non-marital cohabitation concerns the family home. The parent exercising parental rights and the minor child have the right to reside in the apartment (house) owned by the child's other parent (habitatio), (Art. 194 FA). The prerequisite is that the child and the parent exercising parental rights do not have property rights over an unoccupied apartment (house). The right to live in the apartment (house) lasts until the child acquires maturity. The child and the parent would not acquire this right if the acceptance of their request would present manifest injustice to the other parent.

In jurisprudence, the issue if whether manifest injustice existed or not arose in particular cases. The Supreme Court of Serbia reviewed a lower court decision which found that it would be unjust to the defendant if the right to reside was established in favour of his minor child, and reversed the decision as wrongful. The fact that the apartment was a gift to the defendant from his mother did not constitute grounds for the implementation of the legal standard of manifest injustice. The legal standard of manifest injustice does not concern how the ownership right is constituted, but rather about the entire situation of the defendant. This would concern his health, social status, or other circumstances that he could not improve by his actions. The fact that the defendant was a psychologist with a full-time job, and the other circumstances in this case did not indicate the existence of manifest injustice to the defendant. ${ }^{27}$

In other decision concerning the right to reside, the Supreme Court of Cassation of Serbia reviewed a lower court decision, which found that it would not be unjust to the defendant if the right to reside in the apartment that he owned was established in favour of his minor children and ex-wife and upheld the lower court's decision as correct. In the appeal of the lower court's decision, the plaintiff (ex-husband and father of the minor children) claimed that it would be manifest injustice to him to constitute habitatio on his apartment, because he rents this apartment out and, lives in his family house. ${ }^{28}$

\subsection{Maintenance}

The right and obligation of maintenance is one of the effects of marriage/non-marital cohabitation, and of the termination of marriage/non-marital cohabitation, as well (Art.

26 | See more: Kovaček Stanić, 2012, pp. 87-100.

27 | Decision of the Supreme Court of Serbia Rev.1594/06 from November 29, 2006, Bulletin of Court Practice of Supreme Court of Serbia 06/4.

28 | Decision of the Supreme Court of Cassation of Serbia Rev. 3036/2010 of 14 July 2010, (http:// www.vk.sud.rs/sr-lat/rev-303610-pravo-stanovanja-habitatio-mal-dece). 
151,152 FA). A spouse/partner who lacks sufficient means of support, and is unable to work, or is unemployed (without his/her fault), has the right to maintenance from their spouse/ partner in proportion to the latter's capacities. These conditions are objective in nature. Although fault as a category is abandoned in family law, the right to maintenance is not quite objective. The spouse/partner can lose the right to maintenance if the acceptance of their request for maintenance would represent manifest injustice to the other spouse/ partner (Art. 151/3 FA).

Thus, subjective elements is still relevant in maintenance relations. The legal standard of manifest injustice encompasses a variety of specific situations and circumstances, and the courts should concretise this legal standard in their decisions. Case law can consider the reasons for the existence of manifest injustice, which may include violent behaviour, short-lived marriage, long-lasting autonomy of the spouse/partner who seeks the maintenance, or abandoning the spouse/partner without reason.

In its 2017 decision on maintenance proceeding, the Court of Appeal in Belgrade has emphasised the importance of finding the reason why spouse abondoned his sick spouse. ${ }^{29}$ In its decision, the court stressed that for the proper evaluation of whether the petition for maintenance is manifestly unjust or not, it is important to find out if justified reasons for abandoning sick spouse existed.

\section{| 2.5. Exercise of parental rights}

In Serbian law, paternity in marriage is established upon the presumption that the husband of a child's mother is to be considered the father of the child. If a child was born out of wedlock, paternity has to be established by acknowledgment or court judgment (Art. $45 \mathrm{FA}$ ).

Exercising parental rights can take two forms. On the one hand, parents with parental responsibilities can exercise them jointly. Another possibility is the sole exercise of parental rights by only one parent. Joint exercise of parental rights in cases when parents live separately was first introduced into the Serbian legal system by the Family Act 2005. One of the conditions for joint exercise of parental rights in these situations is written agreement between parents.

Case law concerning parental rights after divorce for different periods of time was the topic of an investigation at the Faculty of Law in Novi Sad. The investigation concerned case law in 1969 and 1979, followed by decisions from 1987, 1988, and 1989 issued by two courts of first instance: the High Court in Novi Sad and the High Court in Subotica. In addition, research on the exercise of parental responsibilities after divorce in 2007 and 2016, was conducted at the Basic Court in Novi Sad, which served as a court of first instance in this period..$^{30}$

Over fifty years ago (precisely in 1969) in Serbia mothers exercised parental rights after divorce in $65 \%$ of the cases and fathers in $28 \%$. Over thirty years ago (precisely in 1987 and 1988), children were entrusted to their mothers in about $81 \%$ of the cases and to fathers in $15 \%$. Fifteen years ago (2007), sole exercise of parental rights was ordered in approximately $87 \%$ and joint exercise of parental rights in about $12 \%$. In 2016 sole exercise of parental rights was given to mothers and fathers in $74 \%$ and $9 \%$ of cases, respectively, and joint exercise of parental rights was ordered in $11 \%$ of cases. 
If we bear in mind the fact that even in the cases of joint exercise of parental rights, children mostly live with their mothers, then the percentage of children who live with their mothers increases to $82 \%$. There are significant similarities in the situations 30 years ago, 10 years ago and 5 years ago. However, the situation was different over 50 years ago when fathers exercised parental rights more often than recently (28\% in 1969, vs. 9\% in 2016). This might be explained by the considerable influence of the patriarchal model of parenting 50 years ago in rural settlements, awhile there has been more equal division of roles between parents in the time of socialism in urban settlements.

\section{Draft law on same-sex unions: family law consequences}

The draft law on same-sex unions is under the preparation in Serbia. Draft law 2021 regulates two types of same-sex unions: registered same-sex unions and de facto samesex unions, so a parallelism of the concepts exists.

Registered same-sex union is defined as the union in family life of two same-sex persons, that is concluded by a competent organ. Unregistered (de facto) same-sex union is defined as union of family life of two same-sex persons, which is not concluded by a competent organ. This union has legal effects, only if there are no impediments for its conclusion and if it lasts for at least three years (Art. 2 and Art. 66).

The legal effects of same-sex unions are similar to those of marriage. Personal effects are as follows: same-sex partners consensually and jointly decide on all important matters of their life together, have the right to protect the privacy of their family life and right to mutual cooperation, and have a duty to help each other and care of their partner in times of illness (Art. 30).

Upon conclusion a same-sex union, partners may agree on their surnames. They might decide to retain their separate surnames, adopt either of their surnames, take both surnames, or add their partner's surname to theirs (Art 34). Compared to the surname options available to married couples it can be seen that same-sex partners do not have the option where one of them adopts the surname of the other partner. This is understandable, because in marriage, women usually choose this option; on the contrary, in same-sex union, there is no gender difference.

Some personal legal effects stipulated for spouses are not stipulated for same-sex partners. For instance, spouses are free to make independent decisions on their profession and work. Spouses determine the place of their residence and decide on managing the joint household consensually. In addition, affinity relations are not established in same-sex unions.

Another family law effect concerns property rights. Partners might have separate and community properties, similar to spouses and heterosexual partners in non-marital cohabitation (Art. 38). Contracts on property are available to same-sex partners, during or before conclusion of a same-sex union (Art. 46). Maintenance is the right and duty of partners in same-sex unions, similar to maintenance in marriage (Art. 35).

De facto same-sex union has the same effects on personal relations, the property rights are the same as in registered same-sex union (Art. 67). However, what is noteworthy is that maintenance is not stipulated. It is difficult to understand why maintenance is omitted, considering that the right to maintenance after the termination of a 
legal relationship should be available to spouses, partners in non-marital cohabitation, partners in registered same-sex union, but also partners in de facto same-sex union, as maintenance is one of the effects that is very important to protect the weaker partner.

Same-sex partners in registered unions have inheritance rights in the same way as spouse (Art. 47). On the contrary, same-sex partners in de facto unions do not have inheritance rights, having a similar position to a heterosexual partner in non-marital cohabitation.

The draft law stipulates rights and duties between same-sex partners and a child of either partner. A partner in a same-sex union has the duty to maintain a child of the other partner, if the child does not have relatives who have a duty of maintenance or if they lack sufficient means for maintenance. The duty to maintain a child of the other partner exists even after the death of the child's parent, if cohabitation existed until death. If a same-sex union ceases by annulment or cancellation, a partner's duty to maintain the child of the other partner comes to the end (Art. 36).

A partner in a same-sex union who is not a child's parent has the right to make necessary and urgent decisions in the interest of the child, when there is a danger to the health and life of the child. The partner who makes such a decision has an obligation to immediately inform the child's parent. It seems that during the writing of the draft, fact that the child could have another legal parent, whit parental rights has been overlooked. The legal parent's rights in urgent situations precede those of the same-sex partner.

A partner who is not a child's parent might make day-to-day decisions about the child in agreement with the child's parent in the best interests of the child. If a same-sex union ceases, the child has the right to maintain personal relations with the ex-partner of his/her parent, but this right may be limited by a court decision, when it is in the best interest of the child (Art. 37).

It could be noticed that same-sex partners have a wider scope of rights than stepparents. A step-parent does not have any parental rights, but is subject to the duty of maintenance, according to the Family Act. The child has the right to have personal relationship with the step-parent, but only if he/she is particularly close to him/her (Art. 61/5 FA).

\section{Concluding remarks}

Family law consequences of marriage and non-marital cohabitation are almost similar (property relations, family home, nuptial contract, maintenance, and exercise of the parental rights), but there are difference with respect to surname changes and affinity relations, as these effects do not exist in non-marital cohabitation. In addition, there is also a difference how the paternity is to be established.

The main legal difference between marriage and non-marital cohabitation in other fields of law is that partners do not directly derive inheritance rights from law. In practice, this legal solution causes many problems, as partners are not aware of the provisions of the Law on Inheritance. This is so especially because according to the Family Act, which is the basic act for the regulation of non-marital cohabitation, the consequences of marriage and non-marital cohabitation are almost equal. Bearing in mind the constitutional provision that 'non-marital cohabitation shall be equal with marriage, in accordance with 
the law the confusion in practice is not difficult to explain. It might be said that this legal situation creates not only confusion but also some kind of delusion for partners.

Joint exercise of parental rights after divorce or separation was first introduced into the Serbian legal system by the Family Act of 2005. After two years (2007), joint exercise of parental rights was ordered by courts in $12 \%$ of cases; in 2016, it was ordered in $11 \%$ cases. Thus, this form of exercise of parental rights after divorce was not widely accepted in court practice even more than ten years after its implementation in the legal system. As the condition for joint exercise of parental rights is a written agreement between parents, it might be concluded that the situation in court practise is actually due to lack of acceptance among parents of this form of exercise of parental rights after divorce.

Family law consequences of same-sex union are almost identical to the as consequences of marriage according to the Serbian draft law on same-sex unions. Regarding the exercise of parental rights, same-sex partners have a wider scope of rights than a step-parent: the right to make necessary and urgent decisions as well, day-to-day decisions about the child in agreement with the child's parent in the best interests of the child; even if a same-sex union has ceased, the child still has the right to maintain personal relations with the ex-partner of his/her parent. On the contrary, the step-parent does not have the option of exercising parental rights. The step-parent has only the right and duty to maintain. The child has the right to maintain personal relations with the step-parent, but only if the child is particularly close with step-parent and not unconditionally, as in the case with a same-sex partner. In order to harmonise the legal system, it is of great importance to stipulate the rights of same-sex partners, similar to the rights of a stepparent, or to change rules on the rights and duties of step-parents, before giving these rights to same-sex partners. 


\section{Bibliography}

Boele-Woelki, K. et al., (2004) Principles of European Family Law Regarding Divorce and Maintenance Between Former Spouses. Cambridge: Intersentia.

Boele-Woelki, K. et al., (2007) Principles of European Family Law Regarding Parental Responsibilities. Cambridge: Intersentia.

Bradley, D. (2001). 'Regulation of Unmaried Cohabitation in West-European Jurisdictions - Determination of Legal Policy', International Journal of Law, Policy and the Family 15(1).

I Brown, A. (2019) What is the Family of Law. London: Bloomsbury Publishing.

Cvetić, R. (2016) 'Zajednička svojina supružnika i savesno sticanje pouzdanjem u katastar nepokretnosti (Joint Ownership of Spouses and Good Faith Acquisition of Immovables by Relying on the Real Estate Cadastre)', Proceedings of Novi Sad Faculty of Law 50(3).

Cvetić, R. (2019) 'Nova pravila u postupku upisa u katastar nepokretnosti, upis zajedničke svojina supružnika (New Rules on Registration Procedure with the Real Estate Cadastre. Registration of Common Ownership of Spouses)', Proceedings of Novi Sad Faculty of Law 53(4).

Douglas, G. (2018) Obligation \& Commitment in Family Law. London: Bloomsbury Publishing.

Draghici, C. (2017) The Legitimacy of Family Rights in Strasbourg Case Law. London: Bloomsbury Publishing.

Draškić, M. (2020) Porodično pravo i prava deteta (Family law and rights of a child). Belgrade, Pravni fakultet Univerzieta u Beogradu.

Dwyer, J. G. (2020) The Oxford Handbook of Children and the Law. Oxford University Press.

Huntington C. (2014) Failure to Flourish: How Law Undermines Family Relationships. Oxford: Oxford University Press.

Kovaček Stanić, G. (2008) 'Same-sex Union: A Comparison of the Various European Legal Concepts', Colloquium on Marriage Marriage and quasi-marital relationships in Central and Eastern Europe. Provo: BYA Academy Publishing.

Kovaček Stanić, G. (2010) 'Family autonomy in contemporary parent-child relationships, The International Journal of Jurisprudence of the Family - IJJF 1.

Kovaček Stanić, G. (2012) `Notary Public Authority in Marital/Partnership Relations`, Proceedings of Novi Sad Faculty of Law 46/2.

Kovaček Stanić, G. (2014) Porodično pravo: partnersko, dečje i starateljsko pravo (Family Law: Partnership, Child and Guardianship Law). Novi Sad: Centar za izdavačku delatnost. 
Kovaček Stanić, G. (2014) 'Important Issues Concerning a Child: Decision-making and Resolving the Conflict', Harmonisation of Serbian und Hungarian law with the European Union law: thematic collection of papers. Vol. 2 Novi Sad: Centar za izdavačku delatnost.

Kovaček Stanić, G. Samardžić, S., Kovačević, M. (2017) ‘Razvod braka i zajedničko roditeljsko staranje kao posledica razvoda braka u teoriji i praksi (The Divorce and Joint Parental Responsibilities as a Result of Divorce in Theory and Practice)', Proceedings of Novi Sad Faculty of Law, 51/4.

Kovaček Stanić, G. Samardžić, S. (2019) ‘Assisted Reproductive Technologies: New Family Forms and Welfare of Offspring in Comparative Family Law`, Rogerson C., Antokolskaia M.,Miles J., Parkinson P., Vonk M. (eds.), Family Law and Family Realities, Hague: Eleven, International Publishing.

Kovaček Stanić, G. Samardžić, S. (2020) `Marriage in Serbian law and in Comparative Perspective', Proceedings of Novi Sad Faculty of Law 54/2.

Martin, C., Théry, I. (2001) 'Cohabitataion in France’, International Journal of Law, Policy and the Family15(1).

Rubellin-Devichi, J. (2000) 'How Matters Stand Now in Relation to Family Law Reform', Bainham A. (ed.) The International Survey of Family Law, Bristol: Family Law.

Scherpe, J.M,, Hayward, A. (eds) (2017) The Future of Registered Partnerships, Family Recognition beyond Marriage? Cambridge: Intersentia. 